\title{
Effects of Adding Fat on Rheological Properties of Fish Meat Gel
}

\author{
Yoshinori Mochizuki, ${ }^{* 1}$ Takahide Saito, ${ }^{* 2}$ Naomichi Iso,*2 \\ Haruo Mizuno, ${ }^{* 2}$ Akira Aochi, ${ }^{* 2}$ and Masato Noda*2
}

(Accepted December 18, 1986)

\begin{abstract}
The changes of the rheological properties of fish meat gel which contained various quantities of fat were examined on the bases of the results of differential scanning calorimetry (DSC). Samples were made from the frozen surimi of Alaska pollack and lard. The thermal transition of surimi, ie. gelation, was irreversible, while that of lard was reversible. The thermal transitions of surimi and lard seemed to proceed independently in the mixture. The instantaneous elastic modulus $\left(E_{0}\right)$ of the mixtures decreased with the fat content above the melting point of lard $\left(\mathrm{ca} .29^{\circ} \mathrm{C}\right)$. The decrease corresponded to the increase of sensory "softness". The number of chains per unit volume, $\nu$-value, was given by the temperature dependence of $E_{0}$ of samples according to the theory of rubber elasticity. The $\nu$-values were not changed above $29^{\circ} \mathrm{C}$, but increased with the increase of the fat content at the measuring temperature below $29^{\circ} \mathrm{C}$. The increase of $y$-value below $29^{\circ} \mathrm{C}$ may come from the fact that the crystals of fat behaved like crosslinks. On the other hand, the values did not change above $29^{\circ} \mathrm{C}$, since the fat melted.
\end{abstract}

In the processing "kamaboko" which is a kind of fishmeat gel, ingredients and a method of heating were important factors. Many studies have been published on the rheological properties of fish meat, and also fish meat gel (kamaboko). ${ }^{1-8)}$

In addition, many reports on the thermal analy. sis using differential scanning calorimetry (DSC) of fish meat, meat proteins, and kamaboko have been published..$^{7-11)}$

However, only a few studys on both rheological and thermal properties of surimi was reported. $\left..^{8}, 10\right)$

In this work, we examined rheological properties of fish meat gel having verious content of fat, by the thermal analysis and the stress-strain experiment.

\section{Materials and Methods}

\section{Materials}

Samples were made from the frozen surimi of Alaska pollack (an extra fine quality) and lard, both of which were purchased at a market. The frozen surimi was ground for $7 \mathrm{~min}$ with water $(21 \%)$ and sodium chloride $(2.5 \%)$. Then, the mixture was ground for $7 \mathrm{~min}$ with lard $(0,5,10$, $15,20,25,30,40 \%$ ) and become paste. Thus, obtained the paste was inserted in a poly vinylidene chloride casing ( $55 \mathrm{~mm} \times 220 \mathrm{~mm}$ ) and heated for $1 \mathrm{~h}$ in hot water $\left(85^{\circ} \mathrm{C}\right)$. The paste containing lard, $(25,30,40 \%)$ could not form kamaboko gel by heating.

\section{Differential Scanning Calorimetry}

A portion $(\mathrm{ca} .60 \mu \mathrm{g})$ of sample was transfered to an aluminium hermetic pan and weighed to within $5 \mu \mathrm{g}$. A High Sensitive Differential Scanning Calorimeter (Model SSC-560U, DAINI SEIKOSHA) was used to scan the sample from $10^{\circ} \mathrm{C}$ to $85^{\circ} \mathrm{C}$ at $1.0^{\circ} \mathrm{C} / \mathrm{min}$.

\section{Measuring Compression Instantaneous Elastic Modulus $\left(E_{0}\right)$}

This experiments were carried out by using a Tensipresser (Model TTP-50BX, TAKETOMO DENKI) at $0^{\circ} \mathrm{C}, 10^{\circ} \mathrm{C}, 20^{\circ} \mathrm{C}, 30^{\circ} \mathrm{C}, 40^{\circ} \mathrm{C}, 50^{\circ} \mathrm{C}$, and $60^{\circ} \mathrm{C}$. The plunger was a cylinder of $18 \mathrm{~mm}$ in diameter. A constant strain of 0.25 was selected. Five measurements were taken with the samples heated at the same temperature.

\section{Analysis of $\nu$-values}

According to the theory of rubber elastictiy the

*1 Toyoko Gakuen Women's Junior College, Todoroki, Setagaya, Tokyo 158, Japan (望月䣡篋: 東横学園 女子短期大学).

*2 Department of Food Science and Technology, Tokyo University of Fisheries, Konan, Minato, Tokyo 108, Japan (斍藤隆英, 磯 直道, 水野治夫，青地 昭，野昛真人：東京水産大学). 
stress-tension strain curve of ideal rubber in expressed as follows:

$$
f=\nu R T\left\{(L / L u)^{2}-(L u / L)\right\},
$$

where $R$ is the gas constant, $\nu$ the number of chains per unit volume $\left(\mathrm{mol} / \mathrm{cm}^{3}\right)$, and $T$ the absolute temperature. The $L u$ is the undeformed sample length, and $L$ is the deformed one. We have assumed that the theory of rubber elasticity can be applied to the compression-strain. On the assumption, eq. (1) must be replaced to the following equation,

$$
F=-\nu R T\left\{(L / L u)-(L u / L)^{2}\right\} .
$$

Since the compression elastic modulus, $E$, is defined as

$$
E=L(\partial F / \partial L)_{T},
$$

the combination of eqs. (1') and (2) gives the eq. (3),

$$
E=-\nu R T\left\{(L / L u)+2(L u / L)^{2}\right\} .
$$

In this study, the compression ratio is 0.25 , i.e. $L / L u=0.75$, then we get following relation,

$$
E=-4.3 \nu R T \text {. }
$$

\section{Results and Discussion}

Fig. 1 shows the DSC thermogrames of unheated samples. The thermogram of surimi only $(0 \%$ fat content in Fig. 1) has two endothermic peaks. The peak in the lower temperature region, peak $A$, is mainly due to the thermal transition of myosin or actomyosin and the peak in the higher one, peak B, is due to that of actin, according to Saito et al. ${ }^{\text {) }}$ and Akahane et al. ${ }^{8)}$ The thermogram of lard only ( $100 \%$ fat content in Fig. 1), has one major endothermic peak at temperature of $29^{\circ} \mathrm{C}$, peak $\mathrm{C}$, and some minor ones, peak $\mathrm{D}, \mathrm{E}, \mathrm{F}$, and G. This thermogram is similar to the thermogram which was reported for lard by Imamura et al..$^{12,133}$ and Cornily and Meste. ${ }^{14)}$ The temperature of $29^{\circ} \mathrm{C}$ is corresponded with the melting point of lard. The thermograms of the mixture samples of surimi and lard were similar to the synthetic curve of the thermogram of surimi only and that of lard only.

The total enthalpy change, $\Delta H_{t}$, was estimated by area between a thermogram and the baseline at temperature range from $10^{\circ} \mathrm{C}$ to $85^{\circ} \mathrm{C}$. Table 1 shows the enthalpy changes of unheated samples. Different enthalpy changes $\Delta H_{d}$, were the differences between the total enthalpy change of surimi without lard, and those of surimi with lard. The $\Delta H_{d}$ for each of mixture samples was proportional to the fat content, $5 \%, 10 \%, 15 \%$, and

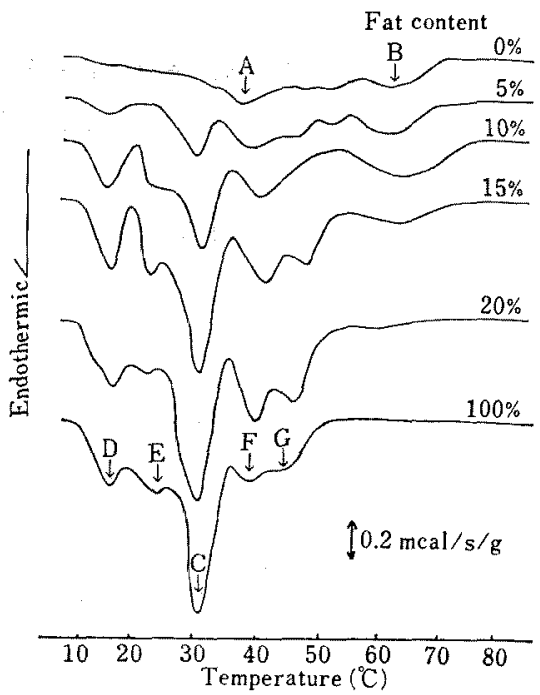

Fig. 1. DSC thermograms of unheated samples.

Table 1. Enthalpy changes of unheated samples

\begin{tabular}{ccc}
\hline $\begin{array}{c}\text { Fat content } \\
(\%)\end{array}$ & $\begin{array}{c}\Delta H_{t}^{* 1} \\
\text { (cal/g) }\end{array}$ & $\begin{array}{c}\Delta H_{d}^{* 2} \\
(\mathrm{cal} / \mathrm{g})\end{array}$ \\
\hline 0 & 0.14 & - \\
5 & 0.40 & 0.26 \\
10 & 0.67 & 0.53 \\
15 & 0.92 & 0.78 \\
20 & 1.17 & 1.03 \\
100 & 5.47 & - \\
\hline
\end{tabular}

*1 $\Delta H_{t}$ : Total enthalpy change.

*2 $\Delta H_{d}$ : Difference enthalpy change. $\Delta H_{d}=\Delta H_{t}-\Delta H_{t}(0 \%)$

$20 \%$, respectively. It is suggested that the thermograms of the mixture could be synthesized quantitatively, from those of surimi and lard.

Fig. 2 and Table 2 show the DSC thermograms and the total enthaipy changes of heated samples, respectively. The thermogram of surimi only $(0 \%$ fat content), has found no peak, but the thermograms of surimi with lard and that of lard only have a major endothermic peak at temperature $29^{\circ} \mathrm{C}$, peak $H$, and some minor peaks, peak I and J. Moreover, each thermogram of surimi with lard was the similar shape as that of lard only. It is suggested that the thermal transition of surimi was irreversible, while that of fat was reversible. The total enthalpy changes of the mixtures, $\Delta H_{t}$ were proportional to the fat contents, as well as those of unheated samples. It may be said from the result that the difference of the rheological properties of heated samples related to the fat content because the thermal transition of lard was reversible. 


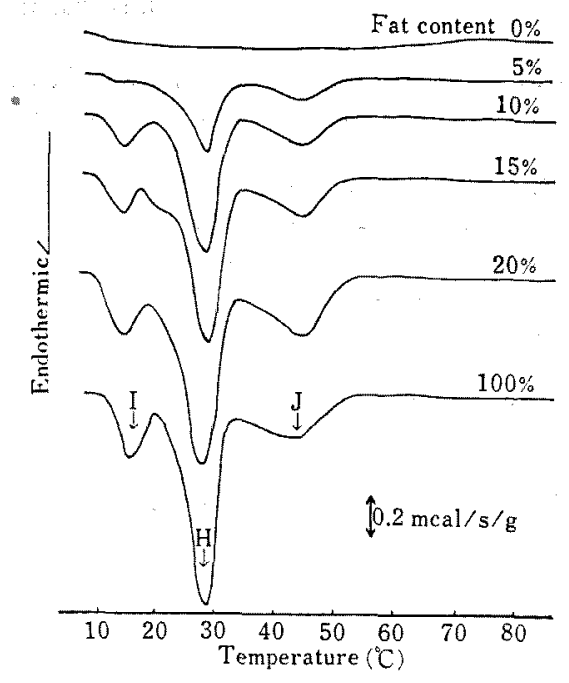

Fig. 2. DSC thermograms of heated samples.

Table 2. Enthalpy changes of heated samples

\begin{tabular}{cc}
\hline $\begin{array}{c}\text { Fat content } \\
(\%)\end{array}$ & $\begin{array}{c}\Delta H_{t}^{*} \\
(\mathrm{cal} / \mathrm{g})\end{array}$ \\
\hline 0 & 0.00 \\
5 & 0.31 \\
10 & 0.64 \\
15 & 0.93 \\
20 & 1.37 \\
100 & 6.27 \\
\hline
\end{tabular}

* $\Delta H_{t}:$ Total enthalpy change.

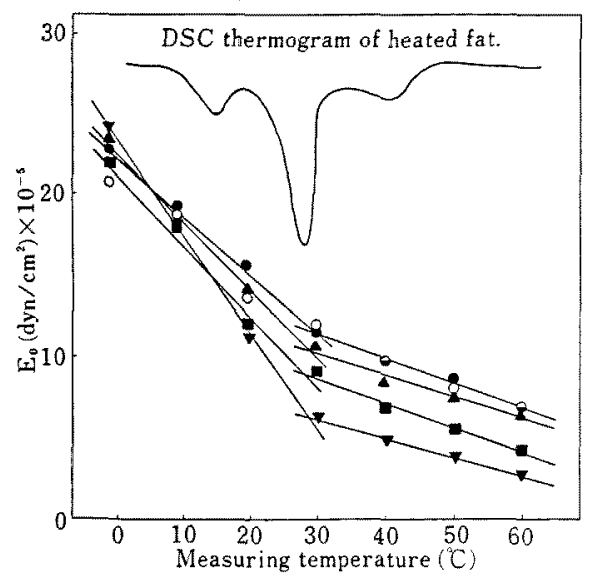

Fig. 3. Dependence of the instantaneous elastic modulus $\left(E_{0}\right)$ on the measuring temperaure.

$0,0 \% ; 0,5 \% ; \Delta, 10 \% ; \mathbf{a}, 15 \% ; \nabla, 20 \%$ fat content.

As shown in Fig. 3, the compression instantaneous elastic modulus, $E_{0}$, decreased with the incre-

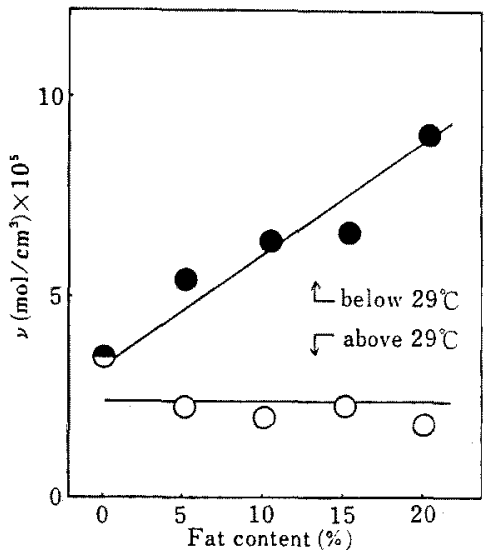

Fig. 4. The relationship between the $\nu$-value and fat content.

ase of measuring temperature. In addition, the $E_{0}$ values decreased with increasing fat content above $29^{\circ} \mathrm{C}$. The decrease of $E_{0}$ may be corresponded to the increase of "softness". The measuring temperature dependence of $E_{0}$ on the mixtures were different between above $29^{\circ} \mathrm{C}$ and below $29^{\circ} \mathrm{C}$.

The $\nu$-values were shown as a function of fat content in Fig. 4. The increase of $\nu$-values below $29^{\circ} \mathrm{C}$ were dependent of the increase of the fat content. However, the $\nu$-values above $29^{\circ} \mathrm{C}$ were independent of the fat content. The temperature of $29^{\circ} \mathrm{C}$ was the melting point of lard. Thus, the $\nu$-values increased apparently with the fat content below the melting point. According to Sherman, ${ }^{18)}$ an unworked fat consists of an interlocking network of fat crystals. Therefore, we assume that the arrangement of fat crystals have the same response as the crosslinks of proteins, when the stress is given to kamaboko with lard below $29^{\circ} \mathrm{C}$. In other words, it may be said that the fat crystals in the mixtures behave like the crosslinks of actomyosin chains in gel. On the other hand, since the fat crystals in the mixtures melted, the $\nu$-values were not changed above the melting point.

\section{References}

1) N. Iso, H. Mizuno, T. Saito, F. Ohzeki, and N. Kurihara: Nippon Suisan Gakkaishi, 50, 10451049 (1984).

2) N. Iso, H. Mizuno, T. Saito, C. Y. Lin, T. Fujita, E. Nagahisa, and Z. Wang: Nippon Suisan Gakkaishi, 51, 1495-1499 (1985).

3) M. Hamada and Y. Inamasu: Nippon Suisan Gakkaishi, 50, 537-540 (1984). 
4) N. Iso, H. Mizuno, T. Saito, F. Ohzeki, and L. C. Yand: Nippon Suisan Gakkaishi, 50, 349-353 (1984).

5) N. Iso, H. Mizuno, T. Saito, Z. Wang, and M. Narita: Nippon Suisan Gakkaishi, 52, 1055-1059 (1986).

6) J. G. Monitejano, D. D. Hamann, and T. C. Lanier: J. Food Sci., 49, 1496-1505 (1984).

7) T. Saito, N. Iso, H. Mizuno, and Y. Mochizuki: Rep. Prog. Polym. Phys. Japan, 27, 745-746 (1984).

8) T. Akahane, S. Chihara, T. P. Niki, T. Sano, T. Tsuchiya, S. F. Noguchi, H. Ookami, and J. J. Matsumoto: Nippon Suisan Gakkaishi, 51, 1844 1486 (1985)

9) M. C. Wu, T. Akahane, T. C. Lanier, and D. D. Hamann: J. Food Sci., 50, 10-13 (1985).
10) M. C. Wu, T. C. Lanier, and D. D. Hamann: J. Food Sci., 50, 20-25 (1985).

11) R. J. Hastings, G. W. Rodger, R. Park, A. D. Matthews, and E. Anderson: J. Food Sci., 50, 503-506 (1985).

12) M. Imamura, I. Niiya, and T. Matsumoto: Yukagaku, 18, 124-131 (1969).

13) M. Imamura, I. Niiya, T. Maruyama, and $T$. Matsumoto: Yukagaku, 18, 171-176(1969).

14) G. Cornily and M. L. Meste: J. Texture Stud, 16, 383-402 (1985).

15) J. R. Quinn, D. P. Raymond, and V.R. Harwalkar: J. Food. Sci., 45, 1146-1149 (1980).

16) P. Sherman: Industrial Rheology, Academic Press, London, 1970, pp. 185-198. 